\title{
Conventional and microwave pyrolysis of a macroalgae waste from the Agar-Agar industry. Prospects for bio-fuel production.
}

\author{
N.Ferrera-Lorenzo, E.Fuente*, J.M.Bermúdez, I.Suárez-Ruiz, B.Ruiz \\ Instituto Nacional del Carbón (CSIC), P.O. Box 73, 33080 Oviedo, Spain
}

\begin{abstract}
A comparative study of the pyrolysis of a macroalgae industrial solid waste (algae meal) in an electrical conventional furnace and in a microwave furnace has been carried out. It was found that the chars obtained from both pyrolyses are similar and show good properties for performing as a solid bio-fuel and as a precursor of activated carbon. Biooils from conventional pyrolysis have a greater number of phenollic, pyrrole and alkane compounds whereas benzene and pyridine compounds are more predominant in microwave pyrolysis with a major presence of light compounds. The bio-gas fraction from microwave pyrolysis presents a much higher syngas content $\left(\mathrm{H}_{2}+\mathrm{CO}\right)$, and a lower $\mathrm{CO}_{2}$ and $\mathrm{CH}_{4}$ proportion than that obtained by conventional pyrolysis. Yields are similar for both treatments with a slightly higher gas yield in the case of microwave pyrolysis due to the fact that microwave heating favours heterogeneous reactions between the gases and the char.
\end{abstract}

Keywords: algae meal, microwave furnace, conventional electrical furnace, bio-fuels, pyrolysis.

\footnotetext{
*Corresponding author. Instituto Nacional del Carbón (CSIC), Francisco Pintado Fe, 26, 33011, Oviedo, Spain. Tel.: +34 9851189 76; fax: +34 985297662 .

E-mail address: enriquef@incar.csic.es (E. Fuente)
} 


\section{Introduction}

Until now the growing demand for energy has been largely satisfied by fossil fuels. However, the legislation in this field is becoming stricter and fossil fuel reserves are limited, stimulating the search for sources of energy such as biomass, especially when this is obtained from agricultural, urban or industrial wastes which have a net zero $\mathrm{CO}_{2}$ impact.

Among the various processes of biomass conversion, pyrolysis is a good method of waste treatment, as it is able to process a wide variety of residues such as municipal solid waste , plastic waste, agricultural residues, sludges, etc. Pyrolysis involves heating the biomass in an inert atmosphere. This process leads to the production of a volatile fraction consisting of bio-gases, a condensable liquids fraction (bio-oils) and a carbon rich solid residue (char). Pyrolysis is seen as a highly versatile process in which it is possible to optimize a variety of variables such as temperature, heating rate, annealing time, etc., depending on whether the desired aim is to maximize the char, oils, or gases (Yanik et al.2013). Moreover, the solid material (char) can be used as potential precursor for activated carbon.

In this study the characteristics of three different pyrolysis fractions (char, bio-oil and bio-gas) obtained from two different methods of heating (conventional and microwave pyrolysis) have been analysed. The first method involves heating in a conventional electrical furnace, whereas the second one consists in subjecting the sample to radiation in a microwave furnace. The main difference between microwave and conventional pyrolysis systems is the heating pattern. In a microwave device, the energy is supplied 
directly to the carbon bed. The conversion of microwave energy is not by conduction or convection as in conventional heating, but by dipole rotation and ionic conduction inside the particles (Deng et al., 2009).The integration of microwaves is a novel conceptual design which could potentially provide an attractive way of pyrolyzing waste and biomass feedstocks (Luque et al., 2012; Yin, 2012).

The material used in this research work, which was obtained from an industry located in northern Spain, is called "alga meal". This industry is one of the highest world producers of Agar-Agar, with the generation of an amount of $2000-2400 \mathrm{~kg} / \mathrm{day}$ of this waste. Currently, a considerable portion of this residue is used for fodder and fertilizer although most of it is disposed off. For this reason a comprehensive and rational utilization of this waste would lead to considerable economic benefits.

Until now pyrolysis of this kind of marine biomass, has been carried out in conventional electrical furnaces, (Ross et al., 2009),(Yanik et al.2013). However, the use of microwaves as a heating method is becoming increasingly widespread, as well noted in some reviews such as the microwave-assisted pyrolysis technique (Motasemi \& Afzal, 2013) or the microwave-assisted pyrolysis of biomass for liquid biofuels production (Yin, 2012). As can be seen, there are several types of biomass and residues which are used for pyrolysis, noting the pyrolysis of oil shales (El harfi et al., 2000), wood (Miura et al., 2004), scrap tyres and plastic waste (Appleton et al., 2005) or sewage sludge (Domínguez et al., 2006; Menéndez et al., 2002). However there are a few works related on the microwave pyrolysis of microalgae (Beneroso et al., 2013; Hu et al., 2012), and no one of macroalgae. Furthermore, microwave-assisted pyrolysis offers the advantage that it saves time and is highly efficient. The disadvantage of this method is that not all materials absorb microwave radiation. The biomass used for this work for example is 
highly transparent to microwaves. Consequently it is necessary to use a microwave receptor such as the pyrolysis char produced in an electrical conventional furnace.

The main objective of this research study is to determine the potential energy use of the chars, and condensable and gaseous products generated from the pyrolysis of marine biomass waste (solid waste originated in the industrial production of Agar-Agar from the algae Gelidium sesquipedale) by means of two treatments: microwave pyrolysis and conventional pyrolysis.

\section{Experimental}

\subsection{Biomass.}

The algae meal studied in this work is a waste generated from the industrial processing of macroalgae of the Gelidium variety, generally Sesquipedale for the production of Agar-Agar. Industrial process stages for obtaining Agar-Agar consist mainly in alkali treatment, washing with acid and water and filtration to remove the Agar-Agar. The resulting product is a residue called "Algae meal" that is free of this polysaccharide. These process has been described in detail in a previous work (Ferrera-Lorenzo et al., 2013).

\subsection{Experimental techniques.}

\subsubsection{Chemical characterization}

The moisture content of the sample was determined following the UNE 32002 norm, based on the determination of weight loss at $105^{\circ} \mathrm{C}$ for 1 hour. The ash content was determined by calcining the sample in a muffle at $815^{\circ} \mathrm{C}$ for 1 hour in the presence of 
oxygen (UNE 32004). For the determination of the carbon, hydrogen and nitrogen contents of the samples a LECO CHN-2000 instruments was employed. The sulphur content was measured using a LECO automatic equipment Determination Sulphur S144-DR. The high heating values (HHV) were determined on an adiabatic IKAcalorimeter $\mathrm{C} 4000$.

The inorganic composition of the biomass (algae meal) was analyzed by ICP-MS and X-ray fluorescence (XRF). For the ICP-MS analysis the sample was dissolved in inorganic acids ( $\mathrm{HNO} 34 \mathrm{~N}$ and concentrated $\mathrm{HCl}$ ). Identification of the elements was carried out on an Agilent 7700x. by diluting the sample and applying external calibration method between 0 and $1000 \mathrm{ppb}$ internal standard (Sc) and a collision cell of He (to eliminate possible matrix interferences). The beads for XRF were prepared by fusing $6 \mathrm{~g}$ of lithium tetraborate for each $0.5 \mathrm{~g}$ of biomass sample $\left(1000^{\circ} \mathrm{C}\right)$ in a PHILIPS Model PERL X́3 automatic fusion bead machine. Elemental analysis was performed in standard conditions on a SIEMENS SRS 3000 XRFWD- XRF spectrometer fitted with an $\mathrm{Rh}$ target tube.

\subsubsection{Pyrolysis process}

The pyrolysis process led to the thermal decomposition of alga meal resulting in three different products: a solid residue (char), a fraction of the condensable volatile matter (oils) and a gaseous fraction.

In this work, pyrolysis was carried out in a microwave furnace and the results obtained were compared with those of conventional pyrolysis from a previous study (FerreraLorenzo et al., 2013). 
The experimental arrangement employed for the pyrolysis of the marine biomass included a unimode-microwave cavity oven. Details of this experimental device have been described previously (Domínguez et al., 2005; Menéndez et al., 2004). The sample was placed in a quartz reactor $\left(40 \mathrm{~cm}\right.$ length $\mathrm{x} 3 \mathrm{~cm}$. i.d.) and a flow of $\mathrm{N}_{2}(100$ $\mathrm{mL} / \mathrm{min}$ ) was used as inert gas. The reactor with the sample was introduced in the center of the microwave guide (Fig.1).

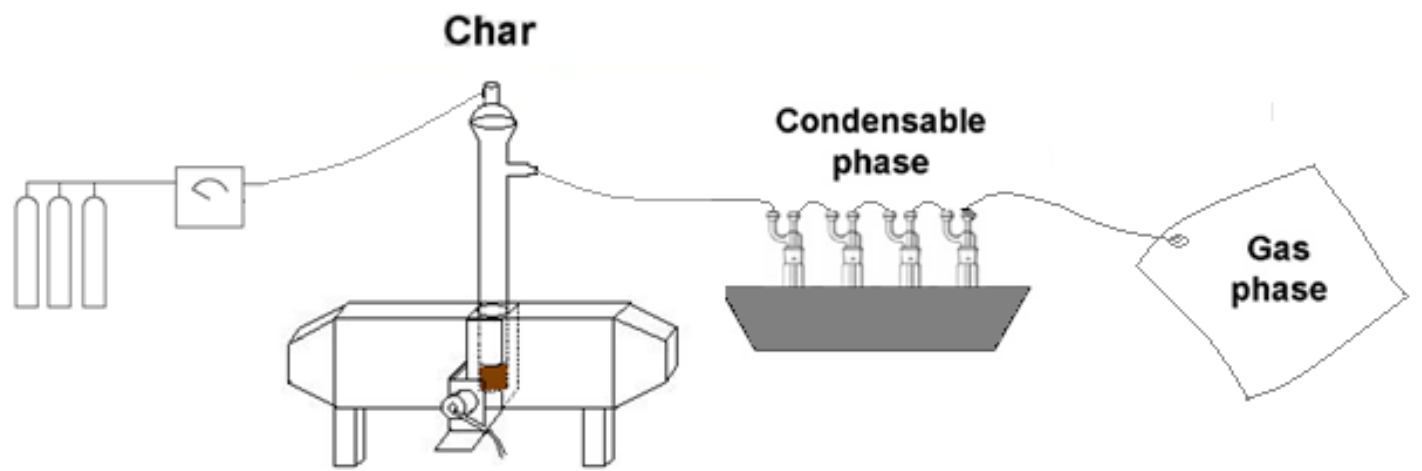

Fig. 1. Experimental set-up for the pyrolysis of algae meal in a microwave furnace.

The carbonaceous residue and the condensable fraction obtained from the pyrolysis in the microwave furnace were weighed in order to calculate yields. The non-condensable gases were collected in Tedlar sample bags of 5-12 L and the gas yield was evaluated by difference.

Algae meal has a very high transparency to microwaves. It was therefore necessary to mix it with an appropriate microwave receptor to achieve the high temperatures required for pyrolysis (Menéndez et al., 2002). About $6 \mathrm{~g}$ of char, obtained in previous experiment in a conventional electrical furnace (Ferrera-Lorenzo et al., 2013) for use as microwave receptor was mixed with $6 \mathrm{~g}$ of raw material. The mixture was then subjected to microwave treatment. 
The required pyrolysis temperature was reached by regulating the microwave power. In order to allow comparison between the results of the conventional and microwave pyrolysis, the operational conditions used were the same as those of the previous work: a final temperature of $750^{\circ} \mathrm{C}$ and an annealing time of 60 minutes (Ferrera-Lorenzo et al., 2013).

The temperature of the sample in the microwave experiments was monitored by an infrared optical pyrometer. Accurate measurement of the evolution of temperature during the process was very difficult due to difficulties inherent in measuring this parameter in microwave devices (Menéndez et al., 1999). For this purpose, it was necessary to calibrate the optical pyrometer by switching off the microwaves and introducing a thermocouple in the centre of the receptor sample. The emissivity parameter was set in the pyrometer in such a way that the temperature measured by both the optical pyrometer and thermocouple would be the same. Once the steady state temperature was reached, this would represent the average temperature of the receptor sample reasonably accurately.

\subsubsection{Chromatographic analysis.}

The chromatographic analysis of the oil fraction was carried out on an Agilent 7890A chromatograph equipped with an Agilent-MS 5975C mass spectrometer. The separation was conducted on a HP-DMS capillary column (5\% phenyl-methylpolysiloxane) (30 $\mathrm{mm} 0.25 \mathrm{~mm}$ ID $\times 0.25 \mu \mathrm{m})$, at an initial temperature of $50^{\circ} \mathrm{C}$ which was maintained for $10 \mathrm{~min}$ at the final temperature. $0.3 \mu \mathrm{l}$ of the sample was injected into the equipment for analysis. The peaks were identified by comparison with NIST08, Wiley $7 \mathrm{n}$ and Wiley 275 library data. Prior to analysis, the moisture of the condensable fraction was 
removed. The aqueous fraction was separated from the organic fraction by decantation. The organic fraction was dissolved in dichloromethane, then dried, using anhydrous sodium sulphate and finally filtered. The filtered solution was evaporated at room temperature during a period of 24 hours and then analyzed by CG-MS.

The chromatographic analysis of the gaseous fraction was performed on a Agilent Technologies 3000A micro-gas chromatograph, equipped with a thermal conductivity detector (TCD) and two packed columns. Quantification was carried out by comparison with established composition patterns. Each sample was injected in volumes ranging up to $100 \mu 1$.

\section{Results and discussion}

\subsection{Chemical analysis of the raw material}

Table 1 shows the results for the proximate and ultimate analyses of the algae meal and the raw algae. It should be noted that in all cases the different macroalgae from the north of Spain, Morocco and Portugal that gave rise to algae meal have with a high carbon content (between 37-45\%), a hydrogen content of around 5\%, a high nitrogen content (3-5\%) and an ash content of 5-18\%. The industrial treatment of macroalgae results in a residue "Algae meal" which has better chemical properties than the raw material (higher carbon, hydrogen and nitrogen contents (43.99\%, 5.95\% and 5.21\% respectively), and a low ash content $7.7 \%$.

The chemical composition of this residue was compared with the results published in the literature for other macroalgae (Ross et al., 2009; Ross et al., 2008).The results of the comparison show a striking similarity. 
Table 1: Proximate and ultimate analysis of macroalgae and algae residue

\begin{tabular}{lcccccc}
\hline Origin & Moisture (\%) & $\mathbf{A s h}(\mathbf{\%})$ & $* \mathbf{C}(\mathbf{\%})$ & $* \mathbf{H}(\%)$ & $* \mathbf{N}(\%)$ & $* \mathbf{S}(\mathbf{\%})$ \\
\hline Llanes & 16,22 & 18,02 & 37,16 & 5,18 & 3,57 & 1,05 \\
Luanco & 15,03 & 14,6 & 39,1 & 5,39 & 5,39 & 3,47 \\
Santander & 14,47 & 7,92 & 43,16 & 5,78 & 3,93 & 0,57 \\
S. Sebastian & 14,23 & 5,53 & 44,53 & 6,01 & 3,93 & 0,97 \\
Marruecos & 13,76 & 16,84 & 37,55 & 5,33 & 3,72 & 1,36 \\
Portugal & 14,59 & 13,11 & 39,01 & 5,46 & 3,28 & 1,42 \\
Algae meal & 7,92 & 7,7 & 43,99 & 5,95 & 5,21 & 1,02 \\
\hline
\end{tabular}

$* \%$, dry basis

The mineral content of algae depends on their location, oceanic residence time and the season as well as on the characteristics of each individual algae species (Ross et al., 2008). From the analysis by ICP-MS and X-ray fluorescence, the most important mineral elements present in the algae meal were established. Table 2 compares the main inorganic element composition of the algae meal in this study with that of other types of algae investigated by Ross et al.(Ross et al., 2008). In the case of some major elements such as $\mathrm{Ca}, \mathrm{Mg}$ and $\mathrm{Si}$ the results are similar. However the macroalgae waste presents $\mathrm{Na}$ and $\mathrm{K}$ contents of 2410 and $960 \mathrm{ppm}$, respectively, which are much lower than the values found in the literature that range from 2000-54000 ppm for $\mathrm{Na}$, and 7000-68000 ppm for K.(Ross et al., 2008; Yanik et al.2013) (Table 2). The lower alkali content in the algae meal may be the result of the chemical pretreatment applied to obtain AgarAgar, as explained in a previous work (Ferrera-Lorenzo et al., 2013). On the other hand, elements such as $\mathrm{Al}, \mathrm{Fe}, \mathrm{Zn}$ and $\mathrm{Mn}$ also present results similar to those reported in the literature, except in the case of $\mathrm{Fe}(510 \mathrm{ppm})$ whose concentration is lower than those obtained by Ross et al. (Ross et al., 2008).

In addition, trace elements were also identified for $\mathrm{Ti}(30 \mathrm{ppm}), \mathrm{Pb}(15 \mathrm{ppm})$ and $\mathrm{Ni}(<6$ ppm) in very low concentrations. Thus it can be concluded that the industrial waste is substantially free of heavy metals. This fact could be an advantage if this waste is 
considered as a possible precursor of activated carbons to be used in the Pharmaceutical and food industry.

Table 2: Comparison of the proportion of inorganic elements between different species of macroalgae studied by A.B.Ross and the algae meal.

\begin{tabular}{|c|c|c|c|c|c|c|c|}
\hline & \multicolumn{7}{|c|}{ MACROMINERALS } \\
\hline & $\begin{array}{c}\text { Fucus } \\
\text { vesiculosus }\end{array}$ & Chorda filum & $\begin{array}{c}\text { Laminaria } \\
\text { digitata }\end{array}$ & Fucus serratus & $\begin{array}{c}\text { Laminaria } \\
\text { hyperborean }\end{array}$ & $\begin{array}{c}\text { Macrocyctis } \\
\text { pyrifera }\end{array}$ & Algae meal \\
\hline $\mathrm{Ca}$ & 10650 & 13450 & 10600 & 21750 & 11600 & 31950 & 23960 \\
\hline $\mathrm{Si}$ & 3060 & 1275 & 1215 & 3705 & 1835 & 5875 & 4380 \\
\hline $\mathrm{Mg}$ & 7710 & 8185 & 9325 & 8435 & 7545 & 10600 & 4390 \\
\hline $\mathrm{P}$ & 24970 & 9770 & 8750 & 14410 & 4870 & 12650 & 3260 \\
\hline $\mathrm{Na}$ & 29350 & 20850 & 43300 & 23050 & 25150 & 54300 & 2410 \\
\hline $\mathrm{K}$ & 37450 & 6885 & 36600 & 24900 & 68450 & 26250 & 960 \\
\hline \multicolumn{8}{|c|}{ MINOR ELEMENTS } \\
\hline $\mathrm{Al}$ & 1275 & 294 & 186 & 1520 & 545 & 1830 & 620 \\
\hline $\mathrm{Fe}$ & 2420 & 2095 & 1980 & 2860 & 2095 & 3500 & 510 \\
\hline $\mathrm{Mn}$ & 66,2 & 7,6 & 29,3 & 291 & 45 & 24,9 & 104 \\
\hline $\mathrm{Zn}$ & 282 & 84 & 205 & 288 & 1225 & 70 & 239 \\
\hline
\end{tabular}

\subsection{Product yields}

Two very different methods of pyrolysis have been compared: conventional pyrolysis in an electrical furnace as studied in a previous work (Ferrera-Lorenzo et al., 2013) and pyrolysis in a single mode microwave. The char, oil and gas yields are presented in Table 3. Comparison of microwave (PMW) and conventional pyrolysis (PC) fraction yields shows that the bio-oil yields are similar whereas the char yield is higher in conventional pyrolysis and the gas yield is higher in microwave pyrolysis. This is due to the presence of char as a microwave receptor which favours secondary reactions leading to the formation of gas, as explained Dominguez et al. (Domínguez et al., 2007). 
Table 3. Comparison of conventional and microwave pyrolysis fractions yields

\begin{tabular}{ccc} 
Yields (\%) & PC & PMW \\
\hline Char & 30.77 & 27.83 \\
Bio-Oil & 35.58 & 35.02 \\
Bio-Gas & 33.65 & 37.15 \\
\hline
\end{tabular}

\subsection{Char}

The optimal pyrolysis conditions (temperature: $750^{\circ} \mathrm{C}$; heating rate: $5^{\circ} \mathrm{C} / \mathrm{min}$, time at final temperature: $60 \mathrm{~min}$; flow of inert gas $\left(\mathrm{N}_{2}\right): 150 \mathrm{ml} / \mathrm{min}$.) were selected from the experiments carried out in the thermobalance as well as a previous study of pyrolysis of algae meal as described in a previous work (Ferrera-Lorenzo et al., 2013).

The results of the proximate and ultimate analyses as well as the $\mathrm{H} / \mathrm{C}$ and $\mathrm{H} / \mathrm{O}$ atomic ratios of the chars obtained from the conventional (PC) and microwave pyrolysis (PMW) of algae meal, are presented in Table 4. It can be seen that there is a significant increase in the carbon content of the char (65.48-70.0\%) compared to the original seaweed meal (43.99\%). However, whereas nitrogen maintains a constant value in the sample pyrolyzed in the PC, it undergoes a decrease in the PMW sample. This result would appear to favour PC pyrolysis since the presence of nitrogen in activated carbons is important for applications such as the retention of contaminants (e.g. $\mathrm{H}_{2} \mathrm{~S}, \mathrm{CO}_{2}$, etc) where nitrogen plays an important role to their retention (Budaeva \& Zoltoev, 2010; Sevilla et al., 2012).

The char resulting from microwave pyrolysis also has a lower carbon content than that obtained from conventional pyrolysis due to the following gasification reaction (Domínguez et al., 2007) :

$\mathrm{C}(\mathrm{s})+\mathrm{CO}_{2}(\mathrm{~g}) \leftarrow \rightarrow 2 \mathrm{CO}(\mathrm{g}) \Delta \mathrm{H}_{298 \mathrm{~K}}=173 \mathrm{~kJ} / \mathrm{mol}$ 
The condensation reactions in the carbonaceous structure during pyrolysis are mainly due to the loss of hydrogen and oxygen, and judging from the oxygen values of the chars, the degree of condensation is higher in the microwave furnace.

From all results it can be conclude that the char from both pyrolysis is a suitable material as precursor of activated carbon given its high carbon content (65-70\%) and nitrogen content (3.9-5.4\%) being appropriate precursor of activated carbons for some applications such as $\mathrm{CO}_{2}$ capture. Furthermore, the char yield of both pyrolysis (27$30 \%)$ and the high heating values $(24.23-25.49 \mathrm{MJ} / \mathrm{kg})$ of the char, are good properties that allow these materials can be used as solid fuel.

Table 4. Chemical composition and high heating values of the char from the conventional (PC) and microwave (PMW).

\begin{tabular}{c|cccc}
\hline \multirow{2}{*}{ \% dry basis } & PC & PMW & Algae meal \\
\cline { 2 - 4 } & \multicolumn{3}{|c}{ Char } & raw material \\
\hline $\mathrm{C}$ & 70.00 & 65.48 & 43.99 \\
$\mathrm{H}$ & 1.07 & 0.77 & 5.95 \\
$\mathrm{~N}$ & 5.42 & 3.92 & 5.21 \\
$\mathrm{~S}$ & 1.02 & 1.37 & 1.02 \\
$\mathrm{O}$ & 21.16 & 28.46 & 36.13 \\
$\mathrm{H} / \mathrm{C}$ & 0.20 & 0.14 & 1.63 \\
$\mathrm{H} / \mathrm{O}$ & 0.91 & 0.43 & 2.63 \\
$\mathrm{HHV}(\mathrm{MJ} / \mathrm{kg})$ & 25.49 & 24.23 & 18.35 \\
\hline
\end{tabular}

\subsection{Oil fraction}

Table 5 shows the values of the elemental composition, the $\mathrm{H} / \mathrm{O}$ and the $\mathrm{H} / \mathrm{C}$ atomic ratios of the algae meal and the bio-oils resulting from pyrolysis in the microwave and conventional electrical furnaces. In all cases, the bio-oils have a lower oxygen content and a higher $\mathrm{H} / \mathrm{O}$ atomic ratio than the raw material. The decrease in oxygen content suggests that a large number of functional groups were lost during pyrolysis at high temperature. The $\mathrm{H} / \mathrm{C}$ values are lower than those for the algae meal, which indicates 
that aromatisation reactions must have occurred (Domínguez et al., 2005). When comparing both methods no major differences were observed, except for a slight increase in carbon content and sulfur in the case of pyrolysis in the microwave furnace. These results are similar to those obtained from the conventional pyrolysis of different types of algae by Wang et al. and Yanik et al. (Wang et al., 2013; Yanik et al.2013). As can be seen in Table 5 the oil obtained from the microwave furnace shows high carbon $(62.84 \%)$ and nitrogen $(9.39 \%)$ contents whereas there is only a slight increase in the hydrogen $(6.42 \%)$ content. These values are generally higher than those reported by the above mentioned authors. The same trend can be observed when these results are compared with those reported in the literature for microalgae (Amin, 2009).

Table 5. Chemical composition and high heating values of the bio-oil from the conventional (PC) and microwave (PMW).

\begin{tabular}{|c|c|c|c|}
\hline \multirow{2}{*}{$\%$ dry basis } & $\mathrm{PC}$ & PMW & \multirow{2}{*}{$\begin{array}{c}\text { Algae meal } \\
\text { raw material }\end{array}$} \\
\hline & \multicolumn{2}{|c|}{ Bio- oil } & \\
\hline $\mathrm{C}$ & 60.84 & 62.84 & 43.99 \\
\hline $\mathrm{H}$ & 6.05 & 6.42 & 5.95 \\
\hline $\mathrm{N}$ & 9.45 & 9.39 & 5.21 \\
\hline $\mathrm{S}$ & 0.56 & 1.06 & 1.02 \\
\hline $\mathrm{O}$ & 23.10 & 20.29 & 36.13 \\
\hline $\mathrm{H} / \mathrm{C}$ & 1.19 & 1.23 & 1.63 \\
\hline $\mathrm{H} / \mathrm{O}$ & 4.19 & 5.06 & 2.63 \\
\hline $\mathrm{HHV}(\mathrm{MJ} / \mathrm{kg})$ & 26.21 & 27.54 & 18.35 \\
\hline
\end{tabular}

Chromatographic analysis was employed to carry out a semi-quantitative analysis of the distribution of the compounds present in the bio-oils, on the basis of the peaks area percentage (Fig. 2 and Table 6). As already explained in a previous work (FerreraLorenzo et al., 2013) carboxylic groups are formed from the pyrolysis of cellulose, whereas phenols and methoxy groups originate from the pyrolysis of lignin(Wang et al., 2013). There are many studies in the literature devoted to the analysis of the condensable fraction obtained from the pyrolysis of microalgae in a conventional 
furnace (Babich et al., 2011) but only a few related to macroalgae. Works related to the pyrolysis of macroalgae include those of Maddi et al. who performed a comparative study of the pyrolysis of algae and lignocellulosic biomass in which they performed a very thorough analysis of chromatographic materials (Maddi et al., 2011), Ju Yoo Bae et al. who analyzed the characteristics of bio-oil produced in the pyrolysis of three kinds of seaweeds (Bae et al., 2011) and A.B. Ross et al. who analyzed the characteristics of the bio-oil obtained from the flash pyrolysis of different types of macroalgae (Ross et al., 2008) . This research group also studied the pyrolysis of brown seaweed before and after pre-treatment with acid and water (Ross et al., 2009). Of the studies based on microwave pyrolysis, worth noting the work of Dominguez et al. (Domínguez et al., 2005) which analyzes the characteristics of bio-oils produced from the microwave pyrolysis of sewage sludge and their study on the pyrolysis of coffee hulls to produce a hydrogen rich fuel gas (Domínguez et al., 2007).

The compounds identified in the microwave pyrolysis of algae meal can be grouped into the following classes: phenols and their derivates including methyl-phenol, ethylphenol, etc; pyrroles and their derivates including carbazoles, indoles, dimethyl-pyrroles or pyrroles joined to pyrazines; furans, naphthalene and their methyl derivates; pyridine and their derivates (mainly methyl pyridine); steroids such as cholestadiene and their isomers; monoaromatic compounds such as benzenes and their derivates; pyrazoles; aliphatic compounds such as alkenes or alkanes and others that cannot be classified into any group as they are minority compounds such as nitriles, ethers or amides. Also worth noting is the presence of nitrogen compounds such as benzonitriles, pentanenitrile, octadecanitriles, etc due to the high nitrogen presence in the algae meal. 
Fig. 3 shows the relative abundances of the above grouped compounds detected by GCMS in the bio-oils obtained from the algae meal by microwave and conventional pyrolysis. There is a greater presence of phenolic compounds, pyrroles and alkanes in the bio-oils from conventional pyrolysis, but a higher content of benzene and pyridine compounds in those obtained from microwave heating. Moreover, comparison of the chromatogram in Fig. 2 with that of a previous PC study (Ferrera-Lorenzo et al., 2013) shows that PMW generates far more lighter compounds than PC, suggesting that microwaves cause more cracking reactions than the conventional furnace. The same observation is made by other authors in the literature such as the study by Domínguez et al. (Domínguez et al., 2005).

Table 6. Composition of the microwave pyrolysis bio-oils of algae meal by GC_MS

\begin{tabular}{|c|c|c|c|}
\hline Peak & $\begin{array}{l}\text { Retention } \\
\text { time (min) }\end{array}$ & Percentage quantified area & Compound \\
\hline 1 & 3.51 & 0.39 & Pyrazine \\
\hline 2 & 3.64 & 0.41 & 2-Propyn-1-ol \\
\hline 3 & 3.74 & 2.39 & Pyridine \\
\hline 4 & 4.13 & 1.55 & 1H-Pyrrole \\
\hline 5 & 4.36 & 1.17 & Toluene \\
\hline 6 & 5.10 & 0.33 & Cyclopentanone \\
\hline 7 & 6.03 & 1.87 & Pyridine, 2-methyl- \\
\hline 8 & 6.38 & 0.81 & Pyrazine, methyl- \\
\hline 9 & 7.29 & 0.27 & ciclohexanona \\
\hline 10 & 7.51 & 0.88 & Pentanenitrile, 4-methyl \\
\hline 11 & 7.52 & & 1H-Pyrrole \\
\hline 12 & 8.02 & 0.82 & 1H-Pyrrole, 3-methyl- \\
\hline 13 & 8.36 & 0.53 & Pyridine, 3-methyl- \\
\hline 14 & 8.47 & 2.13 & Ethylbenzene \\
\hline 15 & 9.01 & 0.60 & $\mathrm{p}+\mathrm{m}$-Xylene \\
\hline 16 & 10.11 & 0.47 & Pyridine, 2,6-dimethyl- \\
\hline 17 & 10.59 & 1.89 & Styrene \\
\hline 18 & 11.59 & & Ethane, diazo \\
\hline 19 & 11.62 & 0.68 & Pyridine, 2-ethyl- \\
\hline 20 & 11.84 & 0.89 & 2-Cyclopenten-1-one, 2-methyl \\
\hline 21 & 12.29 & 2.67 & Ethanone, 1-(2-furanyl)- \\
\hline 22 & 13.45 & 1.16 & Pyridine, 2,4-dimethyl- \\
\hline 23 & 13.78 & 1.13 & 1H-Pyrrole, 2,5-dimethyl- \\
\hline 24 & 14.42 & 0.25 & Pyridine, 2,3-dimethyl- \\
\hline 25 & 16.00 & 0.42 & 2-Cyclopenten-1-one, 3-methyl- \\
\hline 26 & 16.06 & 0.82 & Pyridine, 2-ethyl-6-methyl \\
\hline
\end{tabular}




\begin{tabular}{|c|c|c|c|}
\hline 27 & 17.34 & 0.88 & Benzonitrile \\
\hline 28 & 17.84 & 0.66 & Benzene, 1,3,5-trimethyl \\
\hline 29 & 18.05 & 6.00 & Phenol \\
\hline 30 & 18.26 & 0.83 & Methyl ethyl pyrazine \\
\hline 31 & 18.35 & 0.86 & Pyridine, 4-methoxy \\
\hline 32 & 18.87 & 0.49 & 2-Pyridinamine \\
\hline 33 & 18.95 & 0.83 & N-butyl methyl ether \\
\hline 34 & 19.40 & 0.52 & 1H-Pyrrole, 2-ethyl-4-methyl \\
\hline 35 & 19.92 & 0.71 & 1H-Pyrrole, 2,3,5-trimethyl- \\
\hline 36 & 20.20 & 0.66 & 1,2-Cyclopentanedione, 3-methyl- \\
\hline 37 & 20.84 & 1.72 & Indene \\
\hline 38 & 22.36 & 3.44 & Phenol, 2-methyl- \\
\hline 39 & 22.95 & 0.21 & Cyclooctene \\
\hline 40 & 23.62 & 9.00 & Phenol, 4-methyl- \\
\hline 41 & 24.02 & 1.08 & 1,2-Benzenediamine \\
\hline 42 & 24.36 & 0.43 & Benzofuran, 7-methyl- \\
\hline 43 & 24.49 & 0.75 & Benzene derivade \\
\hline 44 & 24.83 & 0.62 & Phenol, 2,6-dimethyl- \\
\hline 45 & 25.88 & 0.29 & Benzene, (2-methylpropyl) \\
\hline 46 & 26.40 & 0.37 & 4(1H)-Pyridinone, 2,3-dihydro-1-methyl \\
\hline 47 & 26.51 & 1.33 & Benzeneacetonitrile \\
\hline 48 & 26.75 & 0.96 & 2-Methylindene \\
\hline 49 & 27.05 & 2.00 & Benzene, 1-butynyl- \\
\hline 50 & 27.40 & 2.54 & Phenol, 2,4-dimethyl- \\
\hline 51 & 28.20 & 0.59 & E-1,4-dimethyl-1,4-dihydroxy-cyclohexan-2,5-diene \\
\hline 52 & 28.44 & 3.39 & Naphthalene \\
\hline 53 & 28.87 & 0.89 & Phenol, 2,3,5-trimethyl \\
\hline 54 & 29.29 & 0.61 & 5-Dodecene, $(\mathrm{E})$ - \\
\hline 55 & 30.07 & 0.53 & 1,4:3,6-Dianhydro-.alpha.-d-glucopyranose \\
\hline 56 & 30.22 & 0.46 & Benzofuran, 4,7-dimethyl- \\
\hline 57 & 30.76 & 0.46 & 1-Hexyne, 3-ethoxy-3,4-dimethyl- \\
\hline 58 & 31.16 & 0.52 & Isoquinoline \\
\hline 59 & 31.60 & 0.70 & Benzenepropanenitrile \\
\hline 60 & 32.39 & 0.46 & Naphthalene, 1,2,3,4-tetrahydro-2-methyl \\
\hline 61 & 32.88 & 0.53 & 5,4'-Dimethoxy-2-methylbibenzyl \\
\hline 62 & 33.82 & 0.81 & Naphthalene, 2-methyl- \\
\hline 63 & 34.16 & 3.06 & Indole \\
\hline 64 & 34.43 & 0.23 & Tridecane \\
\hline 65 & 34.56 & 0.53 & Naphthalene, 1-methyl- \\
\hline 66 & 36.47 & 0.42 & 1H-Indole, 1,3-dimethyl \\
\hline 67 & 36.76 & 0.66 & Quinoline, 6-methyl \\
\hline 68 & 38.20 & 0.83 & 1H-Indole, 5-methyl- \\
\hline 69 & 38.30 & 0.57 & 1H-Indole, 1-methyl- \\
\hline 70 & 38.48 & 1.24 & 2-Tetradecene, $(\mathrm{E})$ - \\
\hline 71 & 38.58 & 0.68 & 1H-Indole, 2-methyl- \\
\hline 72 & 39.33 & 0.46 & Naphthalene, 1,3-dimethyl- \\
\hline 73 & 39.47 & 0.28 & Naphthalene, 1,5-dimethyl- \\
\hline 74 & 39.97 & 0.45 & 1-Methyl-5-amino-d2-1,2,4-triazole \\
\hline 75 & 41.59 & 1.44 & 2,4-Imidazolidinedione \\
\hline 76 & 42.14 & 0.38 & 1H-Indole, 1-ethyl- \\
\hline 77 & 42.62 & 0.96 & 1-Pentadecene \\
\hline 78 & 42.93 & 0.59 & Pentadecane \\
\hline 79 & 44.78 & 0.62 & 2-Naphthalenamine \\
\hline
\end{tabular}

Benzonitrile

Benzene, 1,3,5-trimethyl

Pheno

1H-Pyrrole, 2-ethyl-4-methyl

1H-Pyrrole, 2,3,5-trimethyl-

1,2-Cyclopentanedione, 3-methyl-

Indene

Phenol, 2-methyl-

Cyclooctene

Phenol, 4-methyl-

1,2-Benzenediamine

Benzofuran, 7-methyl-

Benzene derivade

Phenol, 2,6-dimethyl

4(1H)-Pyridinone, 2,3-dihydro-1-methyl

cetonitrile

Benzene, 1-butynyl-

nol, 2,4-dimethyl

Naphthalene

Phenol, 2,3,5-trimethyl

5-Dodecene, (E)-

1,4:3,6-Dianhydro-.alpha.-d-glucopyranose

Benzofuran, 4,7-dimethyl-

1-Hexyne, 3-ethoxy-3,4-dimethyl-

Isoquinoline

Benzenepropanenitrile

Naphthalene, 1,2,3,4-tetrahydro-2-methy

Naphthalene, 2-methyl-

Naphthalene, 1-methyl-

$1 \mathrm{H}$-Indole, 1-methyl-

2-Tetradecene, (E)-

1H-Indole, 2-methyl-

Naphthalene, 1,3-dimethyl-

Naphthalene, 1,5-dimethyl-

1-Methyl-5-amino-d2-1,2,4-triazole

2,4-Imidazolidinedione

1H-Indole, 1-ethyl- 


\begin{tabular}{|c|c|c|c|}
\hline 80 & 45.43 & 0.40 & 2,4-Imidazolidinedione \\
\hline 81 & 47.51 & 0.78 & 2-methyl-3-(3,4,5-trimethylphenyl)-2-butene \\
\hline 82 & 49.67 & 0.33 & (E)-1-butylidene-2,3-dihydro-4-methylinden-7-ol \\
\hline 83 & 49.81 & 0.44 & 2,4,4-Trimethyl-3-phenyldihydropyran \\
\hline 84 & 50.49 & 0.93 & Heptadecane \\
\hline 85 & 50.61 & 0.39 & Phenol, 3-phenoxy- \\
\hline 86 & 51.57 & 0.21 & Cyclohexane, 2-butyl-1,1,3-trimethyl \\
\hline 87 & 52.90 & 0.23 & Anthracene \\
\hline 88 & 54.45 & 0.50 & $\begin{array}{l}\text { Pyrrolo[1,2-a]pyrazine-1,4-dione, hexahydro-3-(2- } \\
\text { methylpropyl) }\end{array}$ \\
\hline 89 & 55.11 & 0.40 & 9H-Carbazole \\
\hline 90 & 55.30 & 1.26 & $\begin{array}{l}\text { 3,7,11,15-Tetramethyl-2-hexadecen-1-ol } \\
\text { 2-Hexadecene, 3,7,11,15-tetramethyl-, [R-[R*,R*- }\end{array}$ \\
\hline 91 & 55.53 & 0.86 & $(\mathrm{E})]]-$ \\
\hline 92 & 56.71 & 0.66 & 13-Heptadecyn-1-ol \\
\hline 93 & 57.35 & 1.18 & Octadecanenitrile \\
\hline 94 & 57.47 & 0.30 & Octylfuran \\
\hline 95 & 58.19 & 0.49 & $\begin{array}{l}\text { Pyrrolo[1,2-a]pyrazine-1,4-dione, hexahydro-3-(2- } \\
\text { methylpropyl)- } \\
\text { 5,10-Diethoxy-2,3,7,8-tetrahydro- } 1 \mathrm{H}, 6 \mathrm{H} \text { - }\end{array}$ \\
\hline 96 & 58.33 & 0.63 & dipyrrolo $\left[1,2-\mathrm{a} ; 1^{\prime}, 2^{\prime}-\mathrm{d}\right]$ pyrazine \\
\hline 97 & 58.62 & 0.46 & $\begin{array}{l}\text { Pyrrolo[1,2-a]pyrazine-1,4-dione, hexahydro-3-(2- } \\
\text { methylpropyl) }\end{array}$ \\
\hline 98 & 59.79 & 0.56 & 9H-Pyrido[3,4-b]indole \\
\hline 99 & 65.90 & 1.04 & Hexadecanamide \\
\hline 100 & 83.86 & 0.24 & Cholesta-3,5-diene \\
\hline 101 & 85.21 & 0.18 & Cholesta-3,5-diene \\
\hline 102 & 85.37 & 0.26 & Cholesta-4,6-dien-3-ol, $(3 \beta)$ - \\
\hline 103 & 85.63 & 1.50 & Cholesta-3,5-diene \\
\hline
\end{tabular}




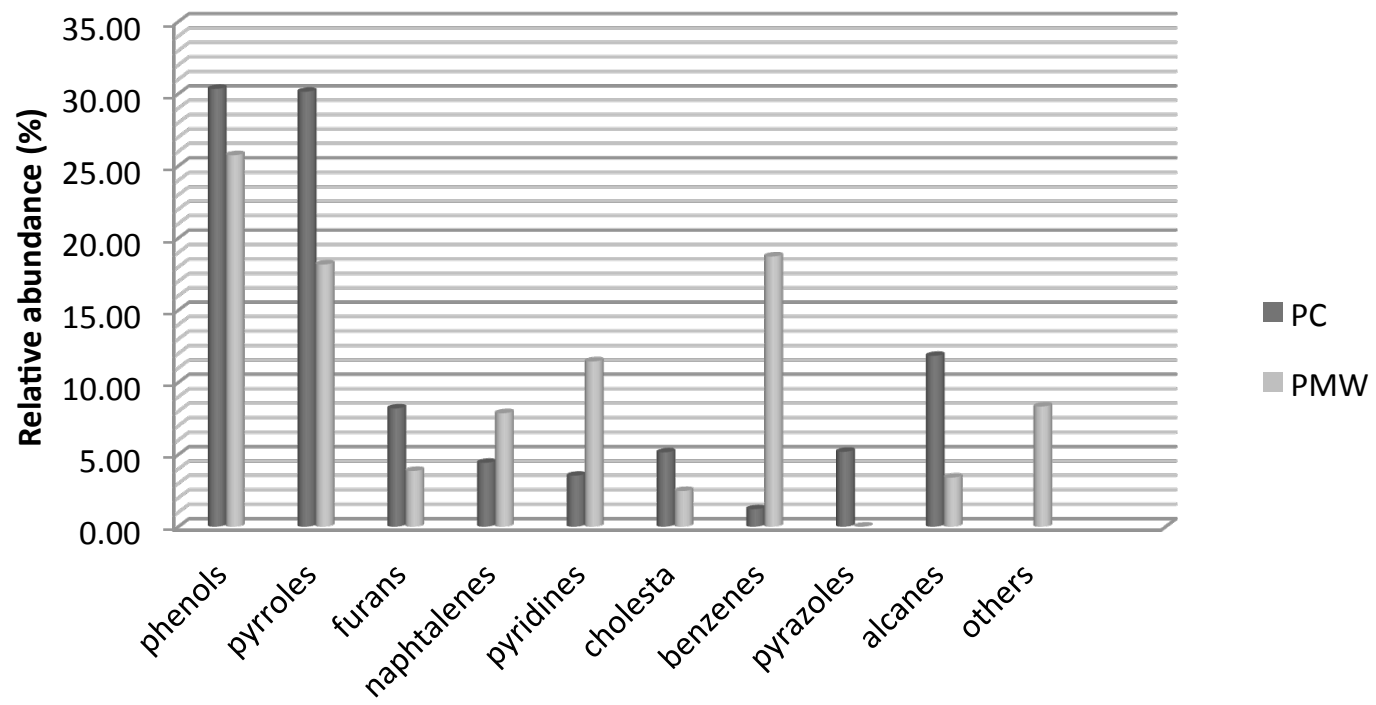

Fig.2. Comparison of the relative abundance of the compounds detected by GC-MS in the bio-oils of algae meal by microwave and conventional pyrolysis.

\subsection{Gaseous fractions}

The compositions of the gas product from conventional (PC) and microwave pyrolysis (PMW) are shown in Table 7. The main gases produced were $\mathrm{H}_{2}, \mathrm{CO}, \mathrm{CO}_{2}, \mathrm{CH}_{4}, \mathrm{C}_{2} \mathrm{H}_{4}$ and $\mathrm{C}_{2} \mathrm{H}_{6}$. The formation of these gaseous compounds is a consequence of cracking reactions and the reactions between the species formed during pyrolysis. The origin of $\mathrm{CO}_{2}$ mainly depends on the carboxy groups in the proteins and saccharides present in the macroalgae. $\mathrm{CO}$ is mainly formed from the secondary cracking of volatiles and the reduction of $\mathrm{CO}_{2}$ (Gil et al., 2012). The formation of methane is due to the release of methoxy groups. On the other hand, the higher hydrogen content is most probably caused by the polycondensation of free radicals generated during the pyrolysis and by dehydrogenation reactions in the char (such as the dehydrogenation of ethane to ethylene) and in the bio-oils, such as aromatization, condensation and alkene formation (Wang et al., 2007). 
If the results obtained for the gas fraction are compared, it can be seen that the microwave produces a gas with lower $\mathrm{CO}_{2}, \mathrm{CH}_{4}, \mathrm{C}_{2} \mathrm{H}_{6}$ and $\mathrm{C}_{2} \mathrm{H}_{4}$ contents than the electrical conventional furnace as well as a higher content in $\mathrm{H}_{2}$ and $\mathrm{CO}$. This finding is very important as it shows that microwave pyrolysis contributes to an increase in the production of syngas $\left(\mathrm{H}_{2}+\mathrm{CO}\right)$ (Domínguez et al., 2007).

These results can be attributed to the different types of heating: microwave pyrolysis and conventional pyrolysis. The final pyrolysis temperature is the same in both types of heating employed. However during microwave heating not all the particles are at the same temperature. In the first stage of the process the particles of char used as microwave receptors are at a much higher temperature than the biomass (algae meal), which is heated by the receptor through conduction and convention. This is bound to favour heterogeneous reactions between the organic carbon of the char and the vapours released from the algae meal (equation 1). As the pyrolysis proceeds more char from the algae meal is formed, which in turn increases the amount of material that absorbs microwaves and also the amount of char which is at a high temperature, thereby favouring the conditions for further heterogeneous reactions (Domínguez et al., 2007).

The results in Table 7, suggest that heterogeneous reaction is more favoured by microwave than by conventional pyrolysis. The dry-reforming of hydrocarbons with $\mathrm{CO}_{2}$ or methane decomposition are other possible reactions that might to the formation of $\mathrm{H}_{2}$ and $\mathrm{CO}$ production (Domínguez et al., 2007) as follows:

$\mathrm{CH}_{4}+\mathrm{CO}_{2} \leftarrow \rightarrow 2 \mathrm{CO}+\mathrm{H}_{2} \quad \Delta \mathrm{H}_{298 \mathrm{~K}}=247.9 \mathrm{~kJ} / \mathrm{mol}$ (2)

$\mathrm{CH}_{4} \rightarrow \mathrm{C}+2 \mathrm{H}_{2} \quad \Delta \mathrm{H}_{2 s \mathrm{k}}=75.6 \mathrm{~kJ} / \mathrm{mol}$ 
These reactions are more favoured in microwave pyrolysis due the presence of a higher content of $\mathrm{CO}$ and $\mathrm{H}_{2}$ and a lower content of $\mathrm{CH}_{4}$ and $\mathrm{CO}_{2}$. Alternatively, the homogeneous methane reaction could therefore have a negative effect on $\mathrm{H}_{2}$ production:

$\mathrm{CO}+3 \mathrm{H}_{2} \leftarrow \rightarrow \mathrm{CH}_{4}+\mathrm{H}_{2} \mathrm{O} \quad \Delta \mathrm{H}_{298 \mathrm{k}}=-206.1 \mathrm{~kJ} / \mathrm{mol}(4)$

Therefore the heterogeneous reaction (1) is favoured by microwave pyrolysis (MWP) whereas the homogeneous reaction (4) is favoured in conventional pyrolysis (Menéndez et al., 2004).

Table 7. Composition (vol.\%) and HHV of the gases produced from the conventional (PC) and microwave (PMW) pyrolysis

\begin{tabular}{|c|c|c|}
\hline & $\mathrm{PC}$ & PMW \\
\hline & \multicolumn{2}{|c|}{$(\%, \mathrm{vol})$} \\
\hline $\mathrm{H} 2$ & 22.81 & 51.78 \\
\hline $\mathrm{CH} 4$ & 15.79 & 6.38 \\
\hline $\mathrm{CO}$ & 18.38 & 23.13 \\
\hline $\mathrm{CO} 2$ & 36.09 & 17.64 \\
\hline C2H6 & 2.42 & 0.46 \\
\hline $\mathrm{C} 2 \mathrm{H} 4$ & 1.25 & 0.60 \\
\hline $\mathrm{C} 2 \mathrm{H} 4 / \mathrm{C} 2 \mathrm{H} 6$ & 0.52 & 1.30 \\
\hline $\mathrm{H} 2+\mathrm{CO}$ & 41.19 & 74.91 \\
\hline $\mathrm{H} 2 / \mathrm{CO}$ & 1.24 & 2.24 \\
\hline $\begin{array}{c}\mathrm{HHV} \\
(\mathrm{MJ} / \mathrm{kg})\end{array}$ & 13.90 & 17.24 \\
\hline
\end{tabular}

\subsection{Heating values}

Table 8 shows the high heating values (HHV) obtained for the algae meal and the corresponding pyrolysis fractions from conventional and microwave process. The calorific value of the algae meal is $18.35 \mathrm{MJ} / \mathrm{kg}$, which is in agreement with the 
values found in the literature, for macroalgae and other types of biomass such as wood, fruit waste, agricultural waste, etc. (Demirbaş, 1997).

The high heating value of the bio-oil obtained in the present work was calculated from following equation (Friedl et al., 2005).

$\operatorname{HHV}(\mathrm{MJ} / \mathrm{kg})=\left(3.55 \cdot \mathrm{C}^{2}-232 \cdot \mathrm{C}-2230 \cdot \mathrm{H}+51.2 \mathrm{C} \cdot \mathrm{H}+131 \cdot \mathrm{N}+20600\right) \times 10^{-3}$

As can be seen, the high heating values for the bio-oils and chars are higer than those of the gas fractions and the algae meal. The HHV of the bio-oils and gases are higher when PMW is used, and those of the char are lower compared to $\mathrm{CP}$, which coincides with the findings reported in the literature (Domínguez et al., 2007) in their study of the microwave pyrolysis of coffee hulls for the production of a hydrogen rich fuel gas. The high heating values of the chars obtained in this work are similar to those shown by other types of biomass, brown coal and lignin (Fu et al., 2012). The high heating values of the bio-oil fraction are high and similar to those of bioethanol and other vegetable oils (Demirbaş, 1998), although lower than the values of fuel oil, gasoline or diesel. The heating value of the gas fraction is rather low compared to those of the other fossil fuels, such as natural gas, but they are similar to the values of blast furnace gas or synthetic coal gas (Perry, 1984). All of these results show that the pyrolysis of the algae meal generates products with greater high heating values than the algae meal and that these materials could therefore be used as fuels. 
Table 8 . Heating values of the algae meal and the pyrolysis fractions from the conventional (PC) and microwave (PMW)

\begin{tabular}{ccccc}
\hline HHV(MJ/Kg) & Algae meal & Char & Bio-oil & Bio-gas \\
\hline PC & 18.35 & 25.49 & 26.21 & 13.90 \\
PMW & 18.35 & 24.23 & 27.54 & 17.24 \\
\hline
\end{tabular}

The total energy content in each pyrolysis fraction was obtained by multiplying each yield fraction by the corresponding high heating value of that particular product (Raveendran \& Ganesh, 1996) as follows:

$\mathrm{E}_{\mathrm{i}}=\mathrm{HHV}_{\mathrm{i}} \cdot \mathrm{Y}_{\mathrm{i}}(5)$

where $\mathrm{E}_{\mathrm{i}}$ is the energy content of biomass pyrolysis product $\mathrm{i}$ (char, liquids or gas), $\mathrm{HHV}$ is the corresponding high heating value and $\mathrm{Y}_{\mathrm{i}}$ is the corresponding yield for each fraction.

The percentage distribution of energy in each pyrolysis fraction can be calculated from the equation:

Energy distribution (\%)= $\mathrm{E}_{\mathrm{i}} / \mathrm{HHV}_{\text {algae meal }}(6)$

Fig.4 shows the values of energy distribution (\%) in each fraction for conventional (PC) and microwave pyrolysis (MWP). It should be noted that the main energy contribution is the bio-oil fraction in both treatments, followed by char. There is a greater contribution of energy by the bio-gas when it is subjected to microwave treatment, as a result of the higher syngas content. 


\section{Energy distribution (\%)}

Char Bio-oil Bio-gas Algae meal

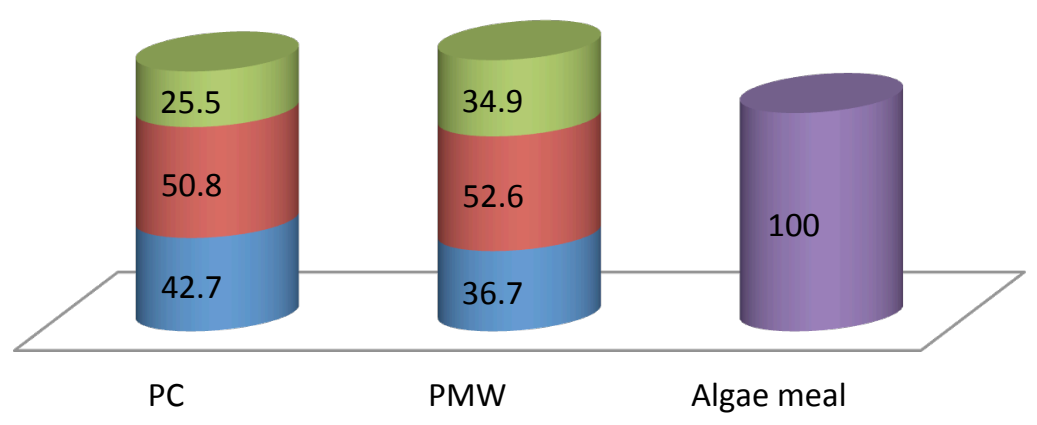

Fig.3. Energy distribution (\%) in each fraction from conventional (PC) and microwave (PMW) pyrolysis.

\section{Conclusions}

Comparison of the conventional and microwave pyrolysis fractions of algae meal shows that the chars obtained from both pyrolyses show good properties as solid fuel and as a precursor for activated carbon. The bio-oils show the highest heating value of all the pyrolysis fractions. Microwave pyrolysis generates lighter compounds than the conventional furnace. The gases of conventional pyrolysis are rich in $\mathrm{CO}_{2}$ whereas the gases generated by microwave pyrolysis contain elevated proportions of syngas (74.91\%). This suggests that the microwave furnace would be more suitable than conventional pyrolysis if the gaseous fraction is being targeted as a source of energy.

\section{$\underline{\text { Acknowledgement }}$}


The financial support for this work was provided by the operating program FEDER of

Principado de Asturias 2007-2013 under the Project PC10-40. The authors thank the

industry for providing the macroalgae industrial residue used in this work.

\section{References}

1.Amin, S. 2009. Review on biofuel oil and gas production processes from microalgae. Energy Convers. Manage, 50, 1834-1840.

2.Appleton, T.J., Colder, R.I., Kingman, S.W., Lowndes, I.S., Read, A.G. 2005. Microwave technology for energy-efficient processing of waste. Appl. Energy, 81, 85-113.

3. Babich, I.V., van der Hulst, M., Lefferts, L., Moulijn, J.A., O'Connor, P., Seshan, K. 2011. Catalytic pyrolysis of microalgae to high-quality liquid bio-fuels. Biomass Bioenergy, 35, 3199-3207.

4. Bae, Y.J., Ryu, C., Jeon, J.-K., Park, J., Suh, D.J., Suh, Y.-W., Chang, D., Park, Y.-K. 2011. The characteristics of bio-oil produced from the pyrolysis of three marine macroalgae. Bioresour. Technol., 102, 3512-3520.

5. Beneroso, D., Bermúdez, J.M., Arenillas, A., Menéndez, J.A. 2013. Microwave pyrolysis of microalgae for high syngas production. Bioresour. Technol., 144, 240-246.

6. Budaeva, A.D., Zoltoev, E.V. 2010. Porous structure and sorption properties of nitrogencontaining activated carbon. Fuel, 89, 2623-2627.

7. Demirbaş, A. 1997. Calculation of higher heating values of biomass fuels. Fuel, 76, 431-434.

7. Demirbaş, A. 1998. Fuel properties and calculation of higher heating values of vegetable oils. Fuel, 77, 1117-1120.

8. Deng, H., Yang, L., Tao, G., Dai, J. 2009. Preparation and characterization of activated carbon from cotton stalk by microwave assisted chemical activation-Application in methylene blue adsorption from aqueous solution. J. Hazard. Mater., 166, 1514-1521.

9. Domínguez, A., Menéndez, J.A., Fernández, Y., Pis, J.J., Nabais, J.M.V., Carrott, P.J.M., Carrott, M.M.L.R. 2007. Conventional and microwave induced pyrolysis of coffee hulls for the production of a hydrogen rich fuel gas. Journal of Analytical and Applied Pyrolysis, 79, 128-135.

10. Domínguez, A., Menéndez, J.A., Inguanzo, M., Pis, J.J. 2005. Investigations into the characteristics of oils produced from microwave pyrolysis of sewage sludge. Fuel Process. Technol., 86, 1007-1020.

11. Domínguez, A., Menéndez, J.A., Inguanzo, M., Pís, J.J. 2006. Production of bio-fuels by high temperature pyrolysis of sewage sludge using conventional and microwave heating. Bioresour. Technol., 97, 1185-1193.

12. El harfi, K., Mokhlisse, A., Chanâa, M.B., Outzourhit, A. 2000. Pyrolysis of the Moroccan (Tarfaya) oil shales under microwave irradiation. Fuel, 79, 733-742.

13. Ferrera-Lorenzo, N., Fuente, E., Suárez-Ruiz, I., Gil, R., Ruiz, B. 2013. Pyrolysis characteristics and kinetics of a macroalgae solid waste generated by the industrial production of Agar-Agar. J.Anal. Appl. Pyrolysis. (Under Review)

14. Friedl, A., Padouvas, E., Rotter, H., Varmuza, K. 2005. Prediction of heating values of biomass fuel from elemental composition. Anal. Chim. Acta, 544, 191-198.

15. Fu, P., Hu, S., Xiang, J., Sun, L., Su, S., Wang, J. 2012. Evaluation of the porous structure development of chars from pyrolysis of rice straw: Effects of pyrolysis temperature and heating rate. J. Anal. Appl. Pyrolysis, 98, 177-183. 
16. Gil, R.R., Girón, R.P., Lozano, M.S., Ruiz, B., Fuente, E. 2012. Pyrolysis of biocollagenic wastes of vegetable tanning. Optimization and kinetic study. J. Anal. Appl. Pyrolysis, 98, 129-136.

17. Hu, Z., Ma, X., Chen, C. 2012. A study on experimental characteristic of microwave-assisted pyrolysis of microalgae. Bioresour. Technol., 107, 487-493.

18. Luque, R., Menendez, J.A., Arenillas, A., Cot, J. 2012. Microwave-assisted pyrolysis of biomass feedstocks: the way forward? Energy \& Environ. Sci., 5, 5481-5488.

19. Maddi, B., Viamajala, S., Varanasi, S. 2011. Comparative study of pyrolysis of algal biomass from natural lake blooms with lignocellulosic biomass. Bioresourc. Technol., 102, 11018-11026.

20. Menéndez, J.A., Domínguez, A., Inguanzo, M., Pis, J.J. 2004. Microwave pyrolysis of sewage sludge: analysis of the gas fraction. J. Anal. Appl. Pyrolysis, 71, 657-667.

21. Menéndez, J.A., Inguanzo, M., Pis, J.J. 2002. Microwave-induced pyrolysis of sewage sludge. Water Res., 36, 3261-3264.

22. Menéndez, J.A., Menéndez, E.M., García, A., Parra, J.B., Pis, J.J. 1999. Thermal treatment of active carbons: A comparison between microwave and electrical heating. J. Microw. Power Electromagn. Energy, 34, 137-143.

23. Miura, M., Kaga, H., Sakurai, A., Kakuchi, T., Takahashi, K. 2004. Rapid pyrolysis of wood block by microwave heating. J. Anal. Appl. Pyrolysis, 71, 187-199.

24. Motasemi, F., Afzal, M.T. 2013. A review on the microwave-assisted pyrolysis technique. Renov. Sustain. Energy Rev., 28, 317-330.

25. Perry, R.H. 1984. Perry's Chemical Engineers Handbook, New York.

26. Raveendran, K., Ganesh, A. 1996. Heating value of biomass and biomass pyrolysis products. Fuel, 75, 1715-1720.

27. Ross, A.B., Anastasakis, K., Kubacki, M., Jones, J.M. 2009. Investigation of the pyrolysis behaviour of brown algae before and after pre-treatment using PY-GC/MS and TGA. J. Anal. Appl. Pyrolysis, 85, 3-10.

28. Ross, A.B., Jones, J.M., Kubacki, M.L., Bridgeman, T. 2008. Classification of macroalgae as fuel and its thermochemical behaviour. Bioresour. Technol., 99, 6494-6504.

29. Sevilla, M., Falco, C., Titirici, M.-M., Fuertes, A.B. 2012. High-performance CO2 sorbents from algae. RSC Adv., 2, 12792-12797.

30. Wang, S., Jiang, X.M., Wang, N., Yu, L.J., Li, Z., He, P.M. 2007. Research on Pyrolysis Characteristics of Seaweed. Energy Fuels, 21, 3723-3729.

31. Wang, S., Wang, Q., Jiang, X., Han, X., Ji, H. 2013. Compositional analysis of bio-oil derived from pyrolysis of seaweed. Energy Convers. Manage, 68, 273-280.

32. Yanik, J., Stahl, R., Troeger, N., Sinag, A. 2013.Pyrolysis of algal biomass. J. Anal. Appl. Pyrolysis, 134-141.

33. Yin, C. 2012. Microwave-assisted pyrolysis of biomass for liquid biofuels production. Bioresour. Technol., 120, 273-284. 